\title{
PORÓWNANIE METOD BADAWCZYCH STOSOWANYCH W ANALIZIE PROCESU ZARYSOWANIA BELKI ZESPOLONEJ
}

\author{
Grzegorz Sadowski, Małgorzata Wydra ${ }^{\bowtie}$ \\ Wydział Budownictwa, Mechaniki i Petrochemii, Politechnika Warszawska, Płock
}

\begin{abstract}
STRESZCZENIE
Przedmiotem artykułu jest analiza porównawcza metod: cyfrowej analizy obrazu, emisji akustycznej i pomiarów zarejestrowanych przez czujniki zegarowe przemieszczeń w analizie procesu zarysowania belki zespolonej. W przypadku badań elementów zespolonych bez zbrojenia zszywającego belki ulegają wyraźnemu zniszczeniu w chwili odpowiadającej utracie przyczepności między betonami. W przypadku elementów ze zbrojeniem zszywającym rozwarstwienie betonu styku następuje w sposób bardziej dyskretny, gdyż zbrojenie przejmuje udział w przenoszeniu sił rozwarstwiających styk, a w konsekwencji nie dochodzi do utraty nośności złącza. Niniejsza praca wykazała przydatność prezentowanych metod do wychwycenia chwili zarysowania styku oraz innych procesów zachodzących w elemencie (zarysowanie strefy rozciąganej oraz uszkodzeń strefy ściskanej przekroju przęsłowego).
\end{abstract}

Słowa kluczowe: cyfrowa korelacja obrazu (DIC), emisja akustyczna (EA), belka zespolona, proces zarysowania

\section{WSTĘP}

Przedmiotem artykułu jest analiza porównawcza metod: cyfrowej analizy obrazu (ang. digital image correlation - DIC), emisji akustycznej (EA) i pomiarów zarejestrowanych przez czujniki zegarowe przemieszczeń $\mathrm{w}$ analizie procesu zarysowania belki zespolonej.

W prezentacji uzyskanych wyników badań skupiono się na trzech aspektach:

- wartości momentu rysującego oraz procesie propagacji rys,

- uszkodzeniu styku warstw betonów wykonywanych w różnych terminach,

- fazie zniszczenia elementu.
Podczas badania elementów żelbetowych najczęściej stosuje się metodę z zastosowaniem czujników zegarowych zlokalizowanych w miejscach, w których planowany jest odczyt odkształceń lub przemieszczeń. W przedstawionym badaniu dodatkowo zastosowano metody EA i DIC. Analizę porównawczą badań wykonanych powyższymi metodami można odnaleźć w artykułach Aggelisa, Verbruggen, Tsangouri, Tysmans i Van Hemelrijcka (2013) oraz Tsangouri, Aggelisa, Van Tittelboom, De Belie i Van Hemelrijcka (2013), w których autorzy badali elementy betonowe wzmacniane włóknami polimerowymi oraz systemy napraw zarysowania. Metody te często są stosowane jako swoje wzajemne uzupełnienie, również $\mathrm{w}$ ocenie stanu technicznego obiektów technicznych (Ranachowski, 2015).

\footnotetext{
$\triangle_{\text {malgorzata.wydra@pw.edu.pl }}$
} 
Cyfrowa korelacja obrazu (DIC) to optyczna bezdotykowa metoda pomiaru współrzędnych do analizy odkształceń i przemieszczeń. Pomiar dla poszczególnych wartości obciążeń wykonuje się na podstawie porównania $\mathrm{z}$ obrazem odniesienia, zwykle $\mathrm{w}$ fazie poprzedzającej obciążenie. Ważnym atutem metody jest możliwość analizowania odkształceń w całej płaszczyźnie poddanej badaniu.

Emisja akustyczna (EA) jest metodą bezinwazyjną, najczęściej wykorzystywaną do badania konstrukcji stalowych w celu wykrycia wad materiałowych. Można ją również wykorzystać w badaniu elementów betonowych w celu wykrycia inicjacji pęknięć, monitorowania rozprzestrzeniania się rys poprzez rejestrowanie liczby zdarzeń akustycznych występujących przy danym obciążeniu. Opracowania wyników badań elementów betonowych analizowanych $\mathrm{z}$ zastosowaniem metody emisji akustycznej można odnaleźć w artykułach Ranachowskiego, Jóźwiak-Niedźwiedzkiej, Brandta i Dębowskiego (2012) oraz Ranachowskiego i Schabowicza (2017).

\section{MATERIAt I METODY}

Badana belka zespolona składała się z dwóch części wykonywanych w różnych terminach. Części te można traktować jako integralny element tylko wtedy, gdy w czasie obciążenia nie nastąpi rozwarstwienie na powierzchni styku pomiędzy prefabrykatem a betonem uzupełniającym. Na nośność styku ma wpływ sposób przygotowania powierzchni prefabrykatu oraz zastosowanie zbrojenia zszywającego. W poprzedniej pracy przedstawiono proces zarysowania i zniszczenia belek zespolonych z różnymi typami przygotowania powierzchni prefabrykatu, bez stosowania zbrojenia zszywającego (Sadowski i Wiliński, 2017). W niniejszym badaniu zastosowano prefabrykat o powierzchni bez dodatkowego przygotowania przed zespoleniem oraz - w odróżnieniu do poprzednio przeprowadzanych badań - ze zbrojeniem zszywającym.

Dolną część belki wykonano 16 marca 2018 roku $\mathrm{z}$ betonu o średniej wytrzymałości na ściskanie $f_{\mathrm{cm} 1}=$ $=30,5 \mathrm{MPa}$. Warstwa betonu uzupełniającego została wykonana 22 marca 2018 roku. Średnia wytrzymałość na ściskanie betonu uzupełniającego wyniosła $f_{c m 2}=38,7 \mathrm{MPa}$. Wytrzymałość na ściskanie została oznaczona w dniu badania (13 kwietnia 2018 r.) na próbkach na próbkach sześciennych o boku $15 \mathrm{~cm}$ przechowywanych w warunkach powietrzno-suchych. Dodatkowo zbadano wytrzymałość na zginanie określaną w statycznej próbie czteropunktowego zginania na beleczkach betonowych $10 \times 10 \times 50 \mathrm{~cm}-$ dla betonu uzupełniającego uzyskano wartość średnią 3,66 $\mathrm{MPa}$, dla betonu prefabrykatu - 3,30 MPa. Do określenia momentu rysującego przyjęto wartość wytrzymałości na rozciąganie betonu prefabrykatu (po uwzględnieniu efektu skali zgodnie z PN-EN 1992-1$-1: 2008)$ równą 2,82 $\mathrm{MPa}$.

Zbrojenie główne (dolne) belki stanowiły pręty żebrowane 3 Ø $20 \mathrm{~mm}$ ze stali B500B, a jako strzemiona dwuramienne zastosowano pręty żebrowane $\varnothing 8 \mathrm{~mm}$ ze stali B500B w rozstawie co $8 \mathrm{~cm}$ w strefie podporowej (na długości $112 \mathrm{~cm}$ po obu stronach elementu), a w pozostałej części belki ich rozstaw wynosił $11 \mathrm{~cm}$. Jeden z prętów głównych został celowo wysunięty poza obrys belki o około $15 \mathrm{~cm}$, aby umieścić na nim sensor niezbędny do badania EA. Dodatkowo pomiędzy warstwami betonów wykonywanych w różnych terminach zastosowano zbrojenie zszywające (strzemiona dwuramienne) w postaci prętów żebrowanych Ø $6 \mathrm{~mm}$ ze stali B500B w rozstawie co $16 \mathrm{~cm} \mathrm{w}$ strefach przypodporowych na długości $112 \mathrm{~cm}$.

Schemat belki zespolonej, rozmieszczenie czujników oraz rozmieszczenie stref rejestracji wyników przez aparaty cyfrowe przedstawiono na rysunku 1. Stanowisko wyposażono w czujniki zegarowe elektroniczne Sylvac S_dial SWISS MODE do wyznaczenia ugięć (czujniki 7-9), odkształceń w środku przęsła belki (czujniki $2-6$, baza pomiarowa $\sim 20 \mathrm{~cm}$ ), przemieszczeń podpór (czujniki 10-13), przemieszczeń warstwy betonu uzupełniającego (czujniki 14-15). Przykładaną siłę odczytywano na podstawie wskazań siłomierza (czujnik 1). Obciążenie przykładano w sposób jednostajny z prędkością $2,7 \mathrm{kN} \cdot \mathrm{min}^{-1}$ aż do zniszczenia elementu.

Równolegle prowadzono analizę z zastosowaniem metody emisji akustycznej oraz wykonywano zdjęcia niezbędne do późniejszej analizy obrazowej w programie GOM Correlate. Na rysunku 1 przedstawiono miejsca wykonywanych zdjęć do analizy obrazowej (I - strefa fotografowana przez aparat I, II - strefa fotografowana przez aparat II). 


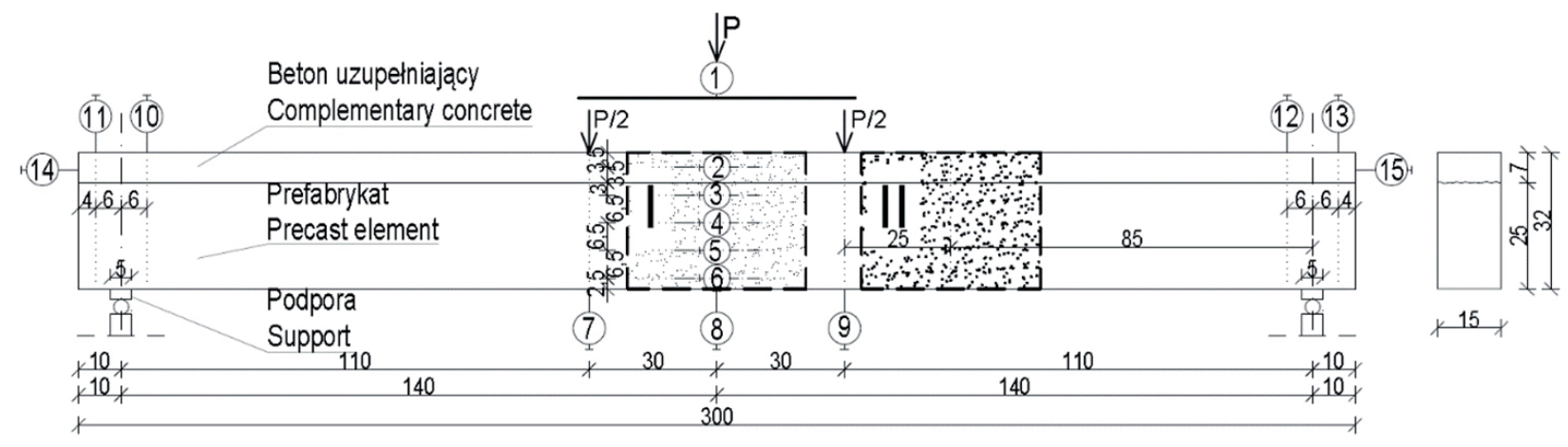

Rys. 1. Schemat belki zespolonej, położenie czujników zegarowych oraz rozmieszczenie stref rejestracji wyników przez aparaty cyfrowe

Fig. 1. Scheme of the composite element, location of dial sensors and image zones of digital cameras

Metoda emisji akustycznej polegała na rejestracji sygnałów powstałych $\mathrm{w}$ belce na skutek zachodzących w niej mikrouszkodzeń w trakcie procesu obciążania. W tym celu zastosowano sensor EA przymocowany do jednego z głównych prętów zbrojeniowych, wysuniętego poza obrys badanej belki (rys. 2a).

Sygnały odbierane przez sensor były przekazywane dalej do analizatora EA. Schemat układu pomiarowego przedstawiono na rysunku $2 \mathrm{~b}$. W celu wyeliminowania zakłóceń pochodzących spoza badanego elementu rejestrowanych w trakcie badania, związanych $\mathrm{z}$ oddziaływaniem otoczenia elementu, przed rozpoczęciem ustalono tzw. sygnał tła, który po zakończeniu badania został odfiltrowany od zarejestrowanego sygnału.

Oprócz opisanych metod zastosowano również metodę DIC. Większość metod obrazowych wymaga odpowiedniego przygotowania powierzchni badawczej. Zalecane jest wprowadzenie na powierzchnię znacz- ników, które będą wykorzystane w procesie przetwarzania zdjęć. Przygotowany element badawczy został pomalowany $z$ jednej strony białą farbą, a następnie naniesiono czarną farbą deseń w postaci małych czarnych kropek. Do badania wykorzystano aparaty cyfrowe o rozdzielczości 12 i 13 Mpx z matrycami CMOS, które wykonywały zdjęcia fragmentu belki o wymiarach $32 \times 42 \mathrm{~cm}$ według rysunku 1 .

Stanowisko z zamontowanymi aparatami stanowiło niezależną konstrukcję. W celu niwelacji efektu cieni belka była oświetlana czterema lampami. Zdjęcia wykonywane były automatycznie co $20 \mathrm{~s}$, a synchronizację z wynikami z czujników zegarowych uzyskano poprzez skorelowanie czasu wewnętrznego aparatów cyfrowych z komputerem.

W związku z tym, że każdy analizowany fragment belki fotografowany był jednym aparatem, wykonano analizę zdjęć metodą cyfrowej korelacji obrazu 2D. Zastosowanie techniki 2D w cyfrowej korelacji

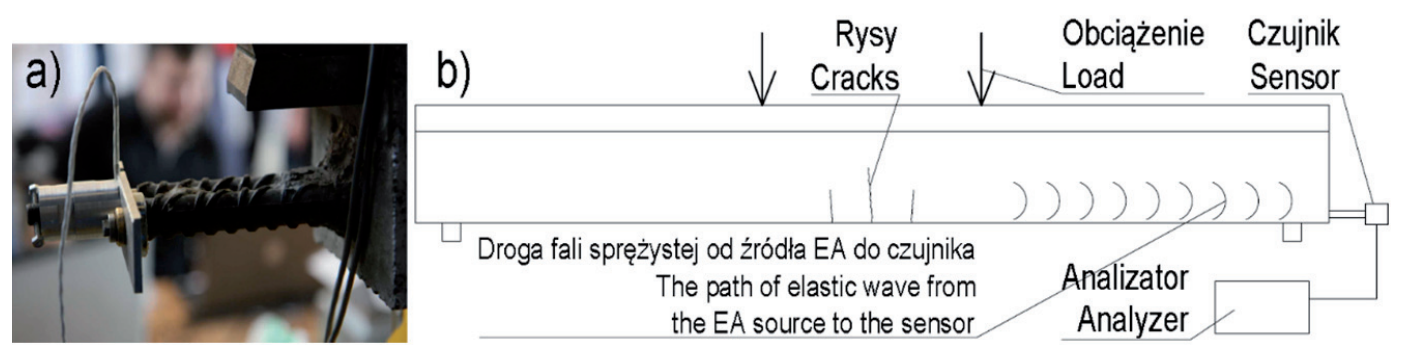

Rys. 2. Zamocowanie sensora EA do pręta głównego belki (a), schemat układu pomiarowego EA (b)

Fig. 2. Mounting of EA sensor to one of the main reinforcement bars (a), scheme of EA measuring system (b) 
obrazu stwarza trudności związane z zasadami optyki (zniekształcenie obrazu). Otrzymane zdjęcia zostały poddane analizie za pomoca oprogramowania GOM Correlate, które działa na zasadzie korelacji i poszukiwania elementów o jednakowych kształtach i określaniu zmiany ich współrzędnych. Charakterystycznym punktom analizowanego obrazu oprogramowanie przyporządkowuje kwadratowe lub prostokątne obszary zwane fasetkami, których rozmiar najczęściej przyjmuje się $15 \times 15$ px. W każdym przypisanym obszarze znajduje się niepowtarzalny deseń, który zostaje bezpośrednio wykorzystany do analizy przemieszczeń i odkształceń. Dokładny opis zasady działania metody DIC oraz sposobu przygotowania i wykonania badań można odnaleźć w publikacji Kowalewskiego, Dietricha, Kopecia, Szymczaka i Grzywny (2016).

\section{WYNIKI I DYSKUSJA}

\section{Zarejestrowane odczyty czujników zegarowych}

Szacowany moment rysujący belki określony na podstawie parametrów zastosowanych materiałów ustalono jako $7,2 \mathrm{kNm}$ zgodnie $\mathrm{z}$ poniższym wzorem:

$$
M_{r}=\frac{f_{f} \cdot b \cdot h^{2}}{6}
$$

gdzie:

$M_{r}-$ moment rysujący,

$f_{f}$ - wytrzymałość na rozciąganie betonu prefabrykatu określona na podstawie wyników zginania beleczek o wymiarach $10 \times 10 \times 50 \mathrm{~cm}$ (po uwzględnieniu efektu skali),

$b$ - szerokość elementu,

$h$ - wysokość elementu.

Moment rysujący zaobserwowany podczas badania na podstawie czujników do pomiaru ugięć określono, wyznaczając punkt załamania wykresu zależności momentu zginającego w początkowej fazie obciążania elementu od jego ugięcia w środku belki. Punkt załamania tego wykresu określono przy wartości momentu równej $10 \mathrm{kNm}$ (rys. 3).

W celu dokładniejszej analizy podzielono początkowy fragment wykresu zależności momentu od ugięcia na części tak, aby każdy $\mathrm{z}$ nich udało się dopasować za pomoca funkcji liniowej $\mathrm{z}$ dopasowaniem $R^{2}$ bliskim jedności. Na rysunku 3 przedstawiono przebieg zależności moment-ugięcie dla całego badania oraz wybrany fragment początkowego etapu badania z dopasowanymi fragmentami zależności liniowych między, gdzie $x$ oznacza ugięcie belki, a $y$ - moment zginający. Wyznaczonym $\mathrm{w}$ ten sposób wartościom momentu przypisano czas ich wystapienia od po-

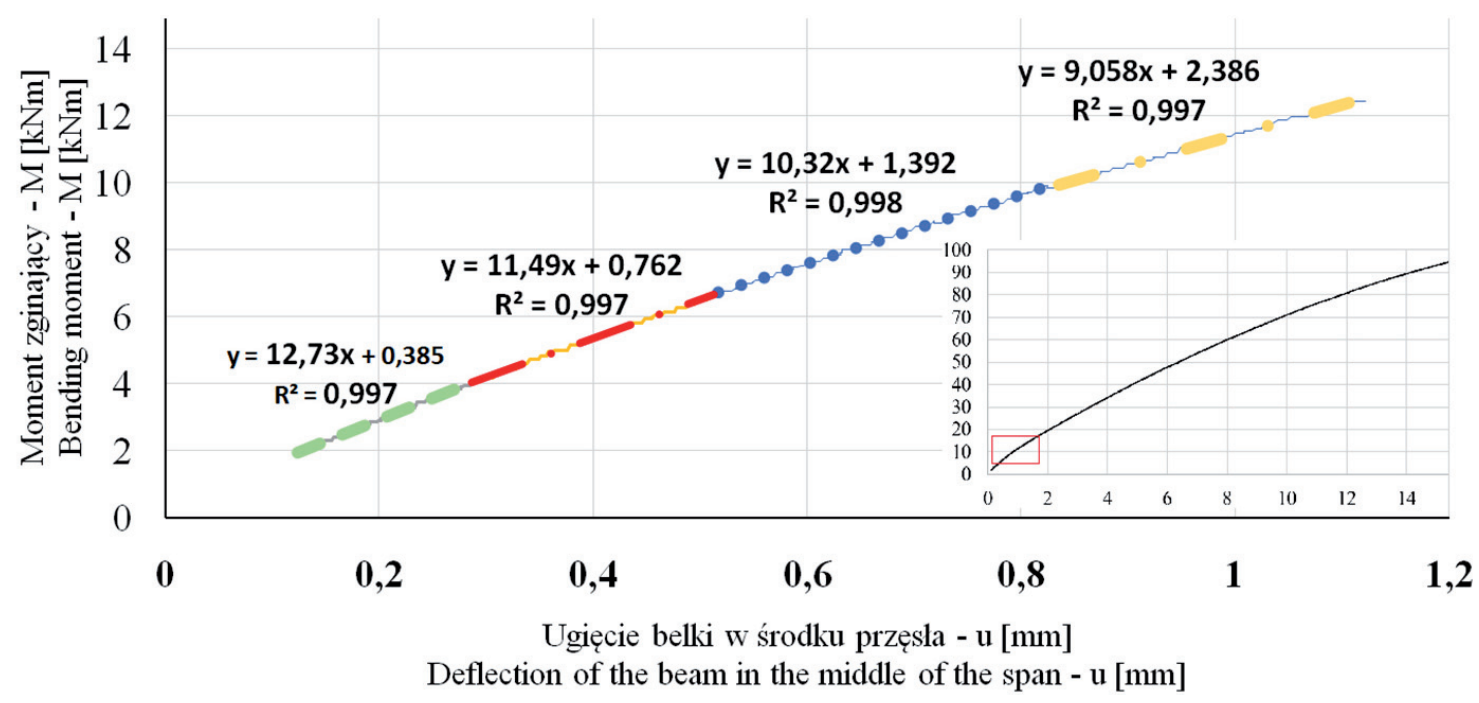

Rys. 3. Wykres moment-ugięcie

Fig. 3. Bending moment-deflection graph 
Sadowski, G., Wydra, M. (2019). Porównanie metod badawczych stosowanych w analizie procesu zarysowania belki zespolonej. Acta Sci. Pol. Architectura 18 (1), 3-12, DOI: 10.22630/ASPA.2019.18.1.1

Tabela. Momenty odpowiadające punktom załamania początkowej części wykresu moment-ugięcie

Table. Bending moment values corresponding with characteristic points of the moment-deflection curve

\begin{tabular}{ccc}
$\begin{array}{c}\text { Czas od początku badania } \\
\text { Time from the beginning of the test } \\
{[\mathrm{s}]}\end{array}$ & $\begin{array}{c}\text { Moment zginający } \\
\text { Bending moment } \\
{[\mathrm{kNm}]}\end{array}$ & $\begin{array}{c}\text { Wartość siły z siłomierza (czujnik 1) } \\
\text { Load value (dial sensor 1) } \\
{[\mathrm{kN}]}\end{array}$ \\
\hline 332 & 4,015 & 7,3 \\
\hline 452 & 6,655 & 12,1 \\
\hline 594 & 10,010 & 18,2 \\
\hline
\end{tabular}

czątku badania, aby umożliwić porównanie wyników z pozostałymi metodami oraz zestawiono je w tabeli.

Na rysunku 4 przedstawiono zależność odkształceń względnych obliczonych na podstawie odczytów z czujników zegarowych rozmieszczonych na wysokości przekroju środkowego (czujniki 2, 3, 4, 5 oraz 6 wg rys. 1) od czasu. Odkształcenia względne obliczono jako:

$\varepsilon=\frac{\Delta l_{i}}{l_{0, i}}$

gdzie:

$\varepsilon$ - odkształcenia względne,

$\Delta l_{i}$ - zarejestrowane wydłużenie/skrócenie bazy pomiarowej,

$l_{0, i}$ - baza pomiarowa czujnika $(\sim 20 \mathrm{~cm})$.
Na rysunku 4 można zauważyć załamanie wykresu (strzałka S3) odpowiadającego odkształceniom względnym obliczonym z odczytów czujnika 6 (czujnik w osi zbrojenia) około $1400 \mathrm{~s}$ od początku badania. Może być to spowodowane tym, że podczas badania zaobserwowano rysę w obszarze bazy pomiarowej tego czujnika.

Stwierdzono zwiększony przyrost odkształceń w strefie ściskanej (zarówno w przypadku czujnika 2, jak i 3) po około 3200-3500 s badania (strzałki S1 oraz S2 na rys. 4). Była to już faza stopniowej degradacji betonu w strefie ściskanej, co będzie można dokładniej zaobserwować w części artykułu poświęconej analizie DIC.

Po około $2500 \mathrm{~s}$ przemieszczenia zarejestrowane przez czujnik 15 zaczęły wzrastać, co zintensyfiko-

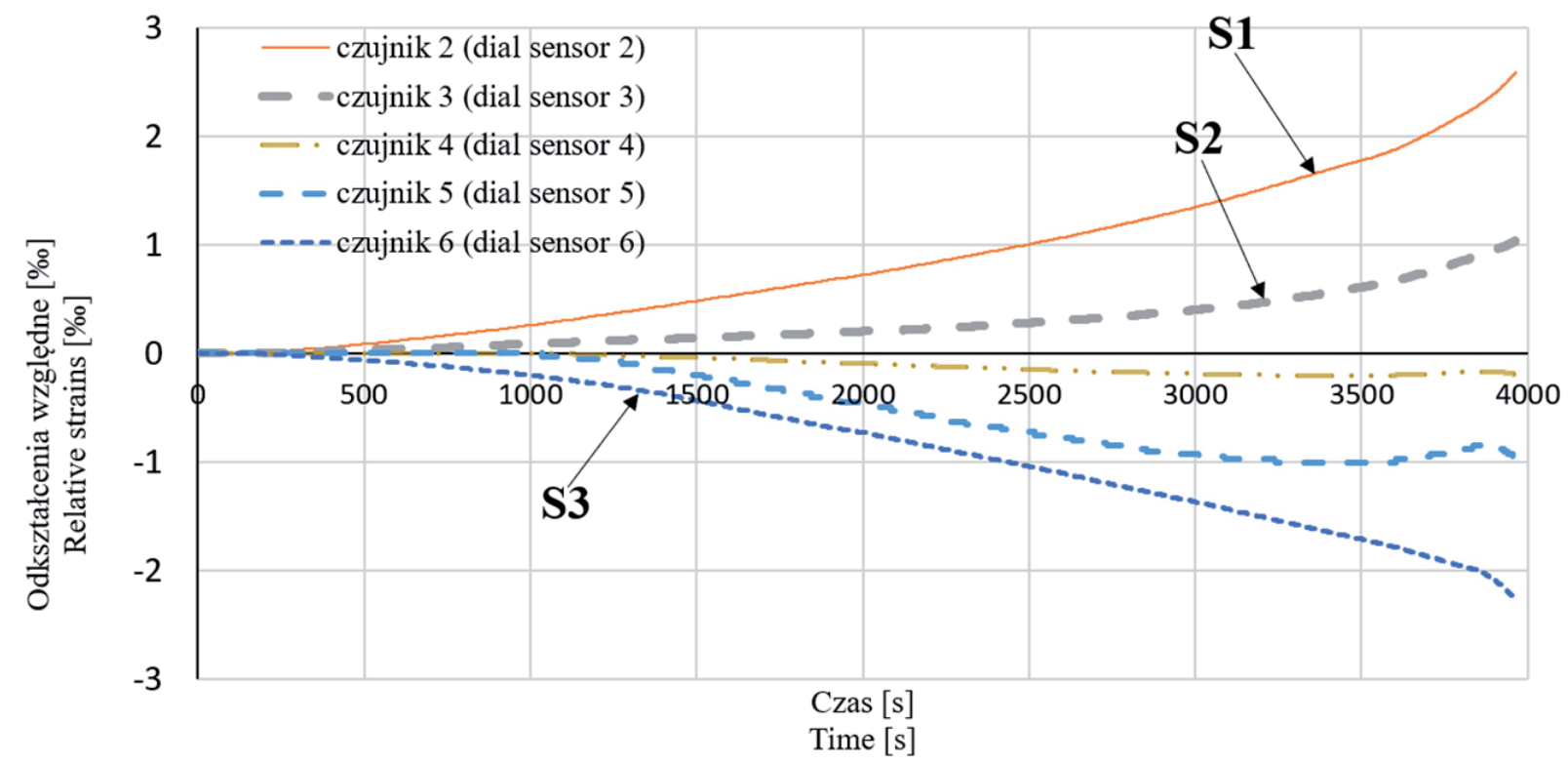

Rys. 4. Zmiany odkształceń względnych w czasie w środku przęsła belki

Fig. 4. Changes of relative strain values for dial sensors located in the middle of the beam span 
Sadowski, G., Wydra, M. (2019). Porównanie metod badawczych stosowanych w analizie procesu zarysowania belki zespolonej. Acta Sci. Pol. Architectura 18 (1), 3-12, DOI: 10.22630/ASPA.2019.18.1.1

wało się w około $3000 \mathrm{~s}$. Następnie zaczęły wzrastać również odczyty czujnika 14 (rys. 5). Powodem może być częściowo postępujące zarysowanie styku pomiędzy warstwami betonów wykonywanych w różnych terminach, a częściowo początek fazy miażdżenia strefy ściskanej betonu między siłami obciążającymi.

Maksymalny moment zginający w całym cyklu obciążania wyniósł $98,12 \mathrm{kNm}$, co odpowiadało wartości na siłomierzu 178,4 kN i nastąpiło w $3953 \mathrm{~s}$ badania przy maksymalnym ugięciu elementu równym $1,74 \mathrm{~cm}$. Maksymalne pomierzone odkształcenia w strefie ściskanej wyniosły $2,79 \%$, a w strefie rozciąganej-3,19\%o.

\section{Metoda emisji akustycznej}

$\mathrm{Na}$ rysunku 6 zaprezentowano wykres zależności energii sygnału EA na jednostkę czasu zarejestrowaną podczas badania. Zaobserwowano fazy rozwoju i wy-

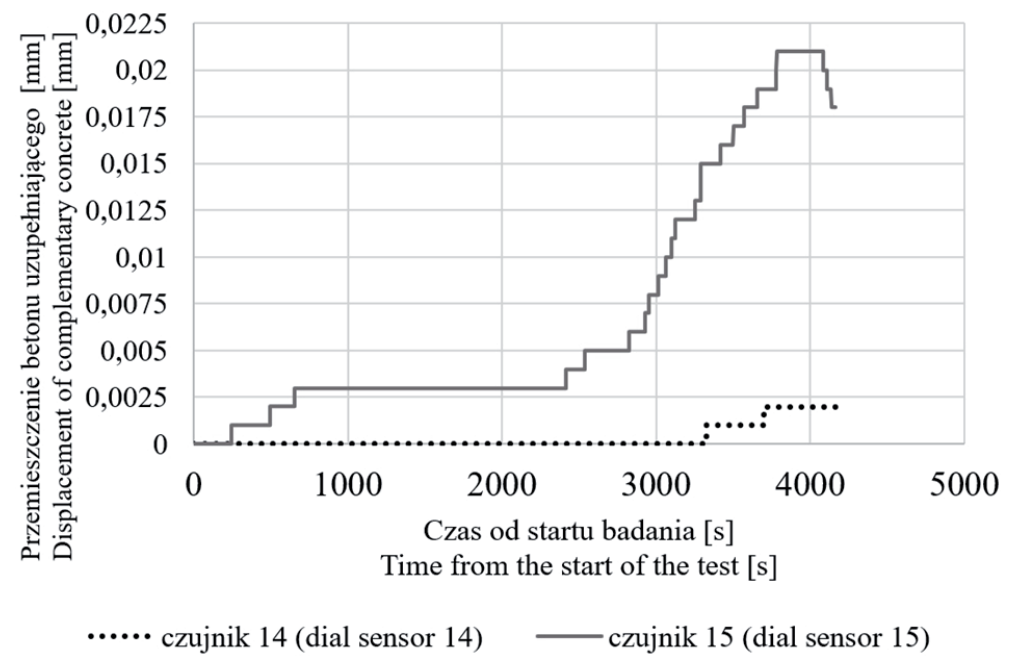

Rys. 5. Wykresy przemieszczeń betonu uzupełniającego odczytanych z czujników mocowanych do czoła belki

Fig. 5. Graph of complementary concrete displacement measured by dial sensors mounted to the left and right side of the beam

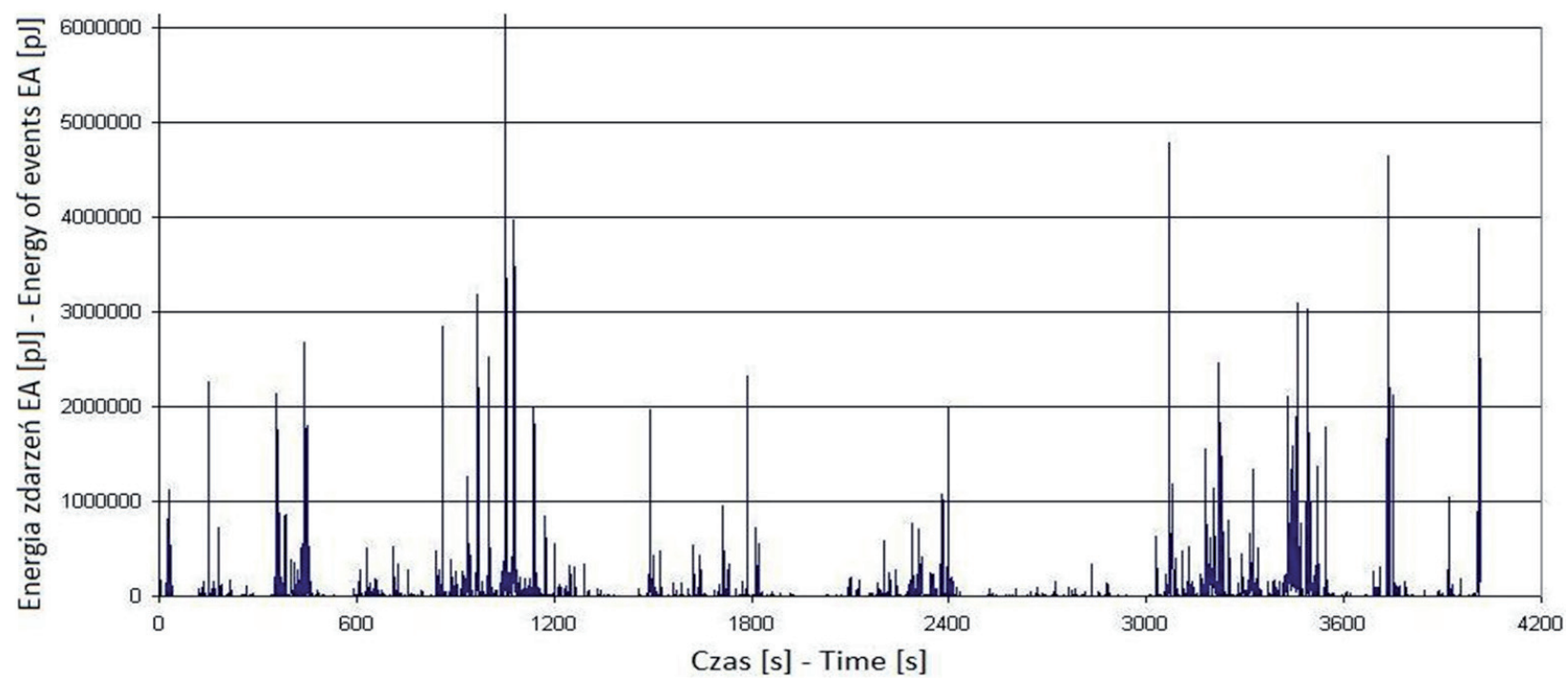

Rys. 6. Energia sygnału EA generowana na jednostkę czasu

Fig. 6. Energy of EA signal generated per unit time 
ciszenia sygnału. Metoda ta umożliwiła w szybki sposób zaobserwować, że w elemencie powstają pewne mikrouszkodzenia, co zostało dalej przeanalizowane z zastosowaniem metody DIC oraz wyników przemieszczeń odczytanych z czujników zegarowych.

Zaobserwowano okresy nasilenia sygnału, a ich początki ustalono w następujących sekundach trwania badania: $300,450,600,800,1400,2100,3000$.

\section{Analiza DIC}

Proces zarysowania belki zespolonej metodą cyfrowej korelacji obrazu został zaobserwowany przy obciążeniu $6,0 \mathrm{kN}$ w miejscu występowania największego momentu zginającego (strefa I wg rys. 1). Wraz ze wzrostem obciążenia można zaobserwować propagację istniejących rys oraz powstawanie nowych. Proces odspojenia w postaci rysy poziomej pomiędzy betonem uzupełniającym, a prefabrykatem został zaobserwowany przy obciążeniu 98,30 kN (w strefie II wg rys. 1), co przedstawiono na rysunku 7.

Po zarysowaniu siły adhezyjne (mechaniczna i specyficzna) mają mniejszy wpływ w przenoszeniu sił rozwarstwiających, a zbrojenie zszywające zaczyna w większym stopniu je przenosić. Dalszy wzrost obciążenia spowodował zwiększenie zarysowania pomiędzy prefabrykatem a betonem uzupełniającym.

$\mathrm{Na}$ rysunku 8 przedstawiono zaobserwowany w obrazie przemieszczeń utworzonym z zastosowaniem programu GOM Correlate proces powstawania rysy w obszarze baz pomiarowych czujników zegarowych (rys. 8), co zostało również odnotowane przy analizie odczytów czujnika 6 (rys. 4). Wraz ze wzrostem obciążenia rysa zwiększa swoją szerokość i długość (rys. 8c).

Na rysunku 9 przedstawiono przemieszczenia zarejestrowane przez aparat I w całym zakresie pracy elementu aż do zniszczenia. Belka zespolona zniszczyła się wskutek przekroczenia wytrzymałości betonu na ściskanie w górnej strefie przekroju pomiędzy przyłożonymi obciążeniami. Przed utratą nośności (rys. 9e) zaobserwowano początkowe przejawy miażdzenia betonu w górnej strefie przekroju (rozwój drobnych, nasilających się stref uszkodzeń), które były wynikiem utraty wytrzymałości betonu na ściskanie. Pierwsze

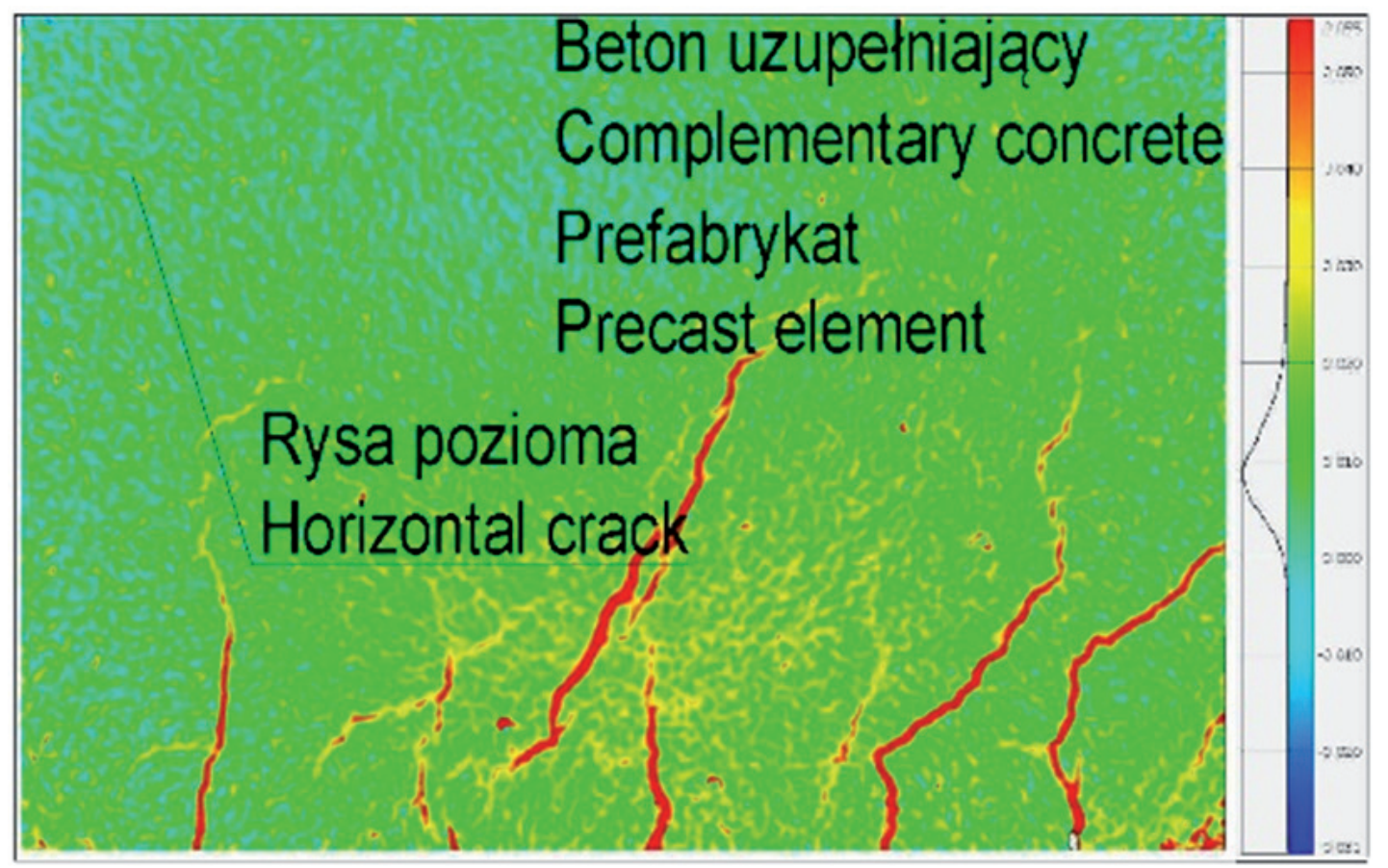

Rys. 7. Przemieszczenia zarejestrowane $\mathrm{z}$ zastosowaniem oprogramowania GOM Correlate - aparat II, obciążenie $P=97 \mathrm{kN}(\sim 2100 \mathrm{~s})$

Fig. 7. Deflection calculated with appliance of GOM Correlate - camera II, load $P=97 \mathrm{kN}(\sim 2,100 \mathrm{~s}$ of the test $)$ 


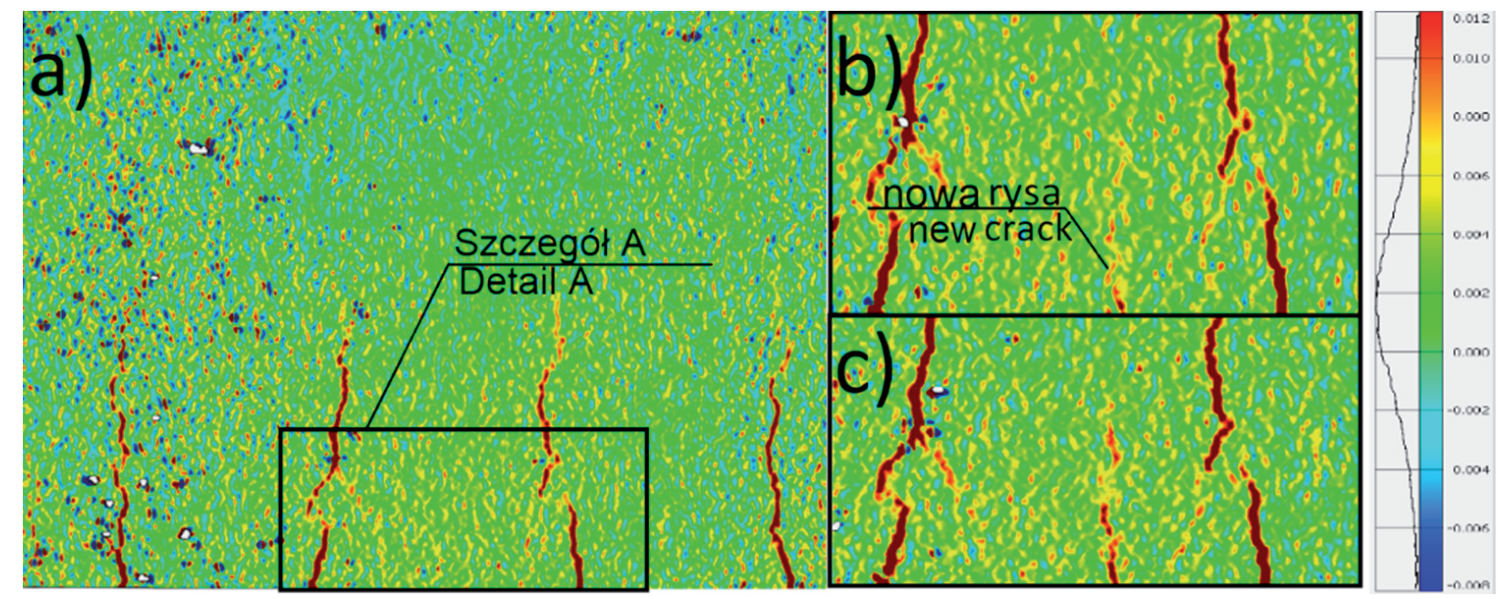

Rys. 8. Przemieszczenia wzdłuż osi podłużnej belki zarejestrowane z zastosowaniem GOM Correlate - aparat I: a - obciążenie $P=44,60 \mathrm{kN}(\sim 1155 \mathrm{~s}$ badania), b - szczegół A obciążenie $P=48,50 \mathrm{kN}(\sim 1225 \mathrm{~s})$, c - szczegół A obciążenie $P=61 \mathrm{kN}(\sim 1440 \mathrm{~s})$

Fig. 8. Displacement along the horizontal axis calculated with appliance of GOM Correlate - camera I: a - load $P=$ $=44.60 \mathrm{kN}(\sim 1,155 \mathrm{~s}$ of the test $), \mathrm{b}-$ detail A load $P=48.50 \mathrm{kN}(\sim 1,225 \mathrm{~s}), \mathrm{c}-\operatorname{detail}$ A load $P=61 \mathrm{kN}(\sim 1,440 \mathrm{~s})$

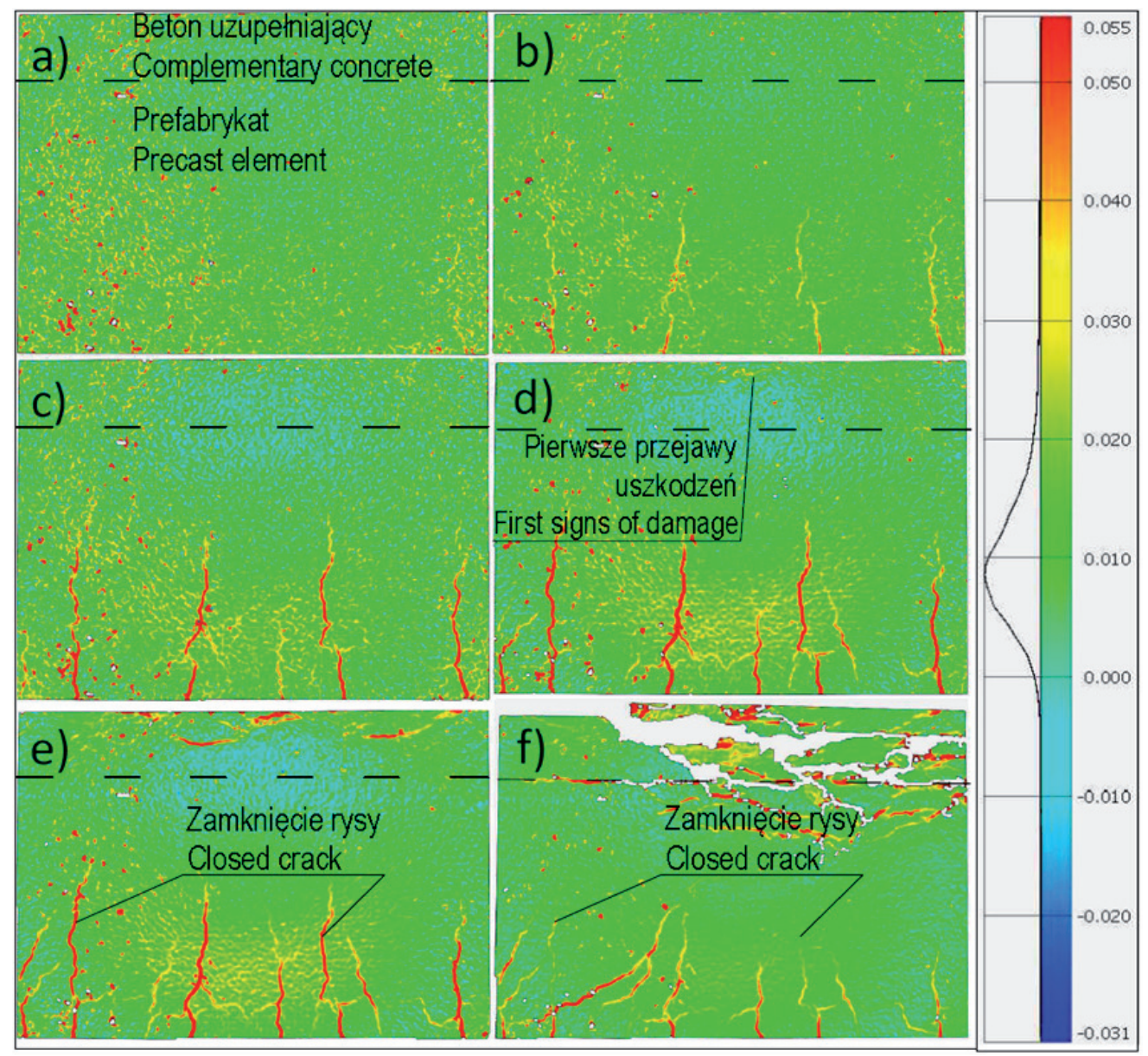

Rys. 9. Przemieszczenia zarejestrowane z zastosowaniem oprogramowania GOM Correlate - aparat I: a - obciążenie $P=12,90 \mathrm{kN}(\sim 470 \mathrm{~s}$ badania), b - obciążenie $P=37,10 \mathrm{kN}(\sim 1010 \mathrm{~s})$, c - obciążenie $P=63,60 \mathrm{kN}$, ( $\sim 1490 \mathrm{~s}), \mathrm{d}-$ obciążenie $P=145,50 \mathrm{kN}(\sim 3050 \mathrm{~s}$ badania $)$, e - obciążenie $P=178,4 \mathrm{kN}(\sim 3950 \mathrm{~s}), \mathrm{f}-$ zniszczenie elementu

Fig. 9. Deflection calculated with appliance of GOM Correlate - camera I: a - load $P=12.90 \mathrm{kN}(\sim 470 \mathrm{~s}$ of the test), $\mathrm{b}-\operatorname{load} P=37.10 \mathrm{kN}(\sim 1,010 \mathrm{~s}), \mathrm{c}-\operatorname{load} P=63.60 \mathrm{kN}(\sim 1,490 \mathrm{~s}), \mathrm{d}-\operatorname{load} P=145.50 \mathrm{kN}(\sim 3,050 \mathrm{~s}), \mathrm{e}-\operatorname{load}$ $P=178.4 \mathrm{kN}(\sim 3,950 \mathrm{~s}), \mathrm{f}-$ damage of the element 
oznaki miażdzenia betonu strefy ściskanej zauważono przy obciążeniu $145,50 \mathrm{kN}$ (rys. 9d), czyli przy około $80 \%$ wartości obciążenia niszczącego. W chwili zniszczenia elementu wielu rys uległo zamknięciu (rys. 9e i 9f), a zmiana naprężeń wewnętrznych spowodowała powstanie nowych w innym miejscu.

Cyfrowa korelacja obrazu pozwala wykryć chwilę powstania rys, określić ich długość $\mathrm{w}$ dowolnym etapie obciążenia badanego elementu oraz zobrazować proces zamykania się niektórych rys $\mathrm{w}$ chwili przegrupowania naprężeń wewnętrznych w badanym elemencie.

\section{Porównanie trzech metod}

Po około $300 \mathrm{~s}$ badania (przy obciążeniu $6 \mathrm{kN}$ ) zaobserwowano nasilenie sygnału EA. Po dokładnej analizie obrazu metodą DIC udało się w tym okresie badania dostrzec pierwsze zarysowanie, a także załamanie wykresu moment-ugięcie opracowanego na bazie odczytów z czujników zegarowych. Załamanie to było trudno zauważalne bez dokładniejszej analizy. Nasilenie sygnału EA zaobserwowano również w około $450 \mathrm{~s}$ badania. Metoda DIC wykazała w tym okresie przyrost długości istniejących rys oraz powstawanie nowych. Następne nasilenie sygnału nastąpiło po około $600 \mathrm{~s}$ (przy obciążeniu $10 \mathrm{kN}$ ). Załamanie wykresu moment-ugięcie było $\mathrm{w}$ tym przypadku łatwiej dostrzegalne na wykresie z pełnego przebiegu badania.

Po około $1400 \mathrm{~s}$ badania (ok. $58 \mathrm{kN}$ ) zaobserwowano ponowne nasilenie sygnału EA. W tym przypadku metoda DIC wykazała pojawienie się nowych rys - w tym między innymi nowej rysy w obszarze bazy pomiarowej czujnika 6 (znajdującego się w osi zbrojenia w środku przęsła belki). Na wykresie zależności odkształceń względnych określonych na podstawie odczytów tego czujnika można było w tym miejscu dostrzec widoczny punkt załamania.

Po około $2100 \mathrm{~s}$ badania (siła $97 \mathrm{kN}$ ) również nastąpiło nasilenie sygnału EA, a za pomocą metody DIC zaobserwowano poziomą linię na wykresie przemieszczeń wygenerowanych przez program GOM Correlate, która odwzorowuje postępujące zarysowanie styku prefabrykatu i warstwy betonu uzupełniającego (rys. 7).
Największa siła obciążająca element w trakcie badania wyniosła $178,4 \mathrm{kN}$, a pierwsze oznaki niszczenia strefy ściskanej (rys. 9d) w przekroju środkowym belki można było zaobserwować (z zastosowaniem metody DIC) już przy około $145 \mathrm{kN}$, to jest przy około $80 \%$ maksymalnego wytężenia elementu. Było to w 3000-3200 s badania. Zjawisku temu towarzyszyło również nasilenie sygnału EA, a także intensywny przyrost odczytów czujników w strefie ściskanej oraz czujników mocowanych do czoła belki.

\section{PODSUMOWANIE}

W procesie badania możliwe było zaobserwowanie za pomocą wszystkich trzech metod faz rozwoju i wyciszenia procesów zachodzących $\mathrm{w}$ elemencie żelbetowym - dotyczy to zarówno zarysowania strefy rozciąganej, warstwy styku betonów wykonywanych $\mathrm{w}$ różnych terminach, jak i procesu powstawania uszkodzeń w miażdżonej strefie ściskanej.

W przypadku badań elementów zespolonych bez zbrojenia zszywającego, przedstawionych $\mathrm{w}$ pracy Sadowskiego i Wilińskiego (2017), belki ulegały wyraźnemu zniszczeniu $\mathrm{w}$ chwili odpowiadającej utracie przyczepności między betonami. W przypadku elementów ze zbrojeniem zszywającym rozwarstwienie styku betonów następuje w sposób bardziej dyskretny, gdyż zbrojenie przejmuje udział w przenoszeniu sił rozwarstwiających styk, a w konsekwencji nie następuje utrata nośności złącza. Niniejsza praca wykazała przydatność prezentowanych metod do wychwycenia chwili zarysowania styku, a więc istnieje możliwość ich stosowania do dalszej analizy belek ze zbrojeniem zszywającym w kontekście udziału sił adhezyjnych betonu oraz naprężeń w stali w przenoszeniu sił rozwarstwiających styk.

W następnych tego typu badaniach należałoby zwrócić uwagę na konieczność wyeliminowania zaburzeń pomiaru w metodzie optycznej związanych z wpływem wad optycznych (dystorsji, winietowania, aberracji chromatycznej i sferycznej) oraz zaproponować rozmieszczenie dodatkowych sensorów EA - należałoby umieścić je nie tylko na pręcie strefy rozciąganej, ale również w strefie ściskanej, co umożliwi precyzyjniejsze określenie, której strefy belki dotyczą zachodzące zmiany. 


\section{ADNOTACJA}

Badania zostały przeprowadzone $\mathrm{w}$ ramach działalności Koła Naukowego Budownictwa „Konstruktor” Politechniki Warszawskiej Filii w Płocku oraz przy współpracy z dr. hab. inż. Zbigniewem Ranachowskim z Instytutu Podstawowych Problemów Techniki Polskiej Akademii Nauk.

\section{PIŚMIENNICTWO}

Aggelis, D. G., Verbruggen, S., Tsangouri, E., Tysmans, T. i Van Hemelrijck, D. (2013). Characterization of mechanical performance of concrete beams with external reinforcement by acoustic emission and digital image correlation. Construction and Building Materials, 47, 1037-1045.

Kowalewski, Z. L., Dietrich, L., Kopeć, M., Szymczak, T. i Grzywna, P. (2016). Nowoczesne systemy optyczne w badaniach mechanicznych - budowa, działanie, za- stosowania, W XXII Seminarium „Nieniszczace badania materiałów", Zakopane, 16-18 marca 2016 r.

Ranachowski, Z. (2015). Zastosowanie emisji akustycznej w diagnostyce obiektów technicznych, W XXI Seminarium „Nieniszczqce badania materiałów”, Zakopane, 18-20 marca $2015 \mathrm{r}$.

Ranachowski, Z., Jóźwiak-Niedźwiedzka, D., Brandt, A. M. i Dębowski, T. (2012). Application of acoustic emission method to determine critical stress in fibre reinforced mortar beams. Archives of Acoustics, 37 (3), 261-268.

Ranachowski, Z. i Schabowicz, K. (2017). The contribution of fiber reinforcement system to the overall toughness of cellulose fiber concrete panels. Construction and Building Materials, 156, 1028-1034.

Sadowski, G. i Wiliński, P. (2017). Badanie wpływu ukształtowania styku na ugięcie żelbetowych belek zespolonych. Inżynieria i Budownictwo, 4, 206-210.

Tsangouri, E., Aggelis, D. G., Van Tittelboom, K., De Belie, N. i Van Hemelrijck, D. (2013). Detecting the activation of a self-healing mechanism in concrete by acoustic emission and digital image correlation. The Scientific World Journal, \#424560. doi: 10.1155/2013/424560

\title{
COMPARISON OF METHODS APPLIED TO ANALYSIS OF CRACK PROPAGATION IN REINFORCED CONCRETE COMPOSITE BEAM
}

\begin{abstract}
The aim of the study is to compare three methods: digital image correlation, acoustic emission and method with the application of dial sensors in analysis of crack propagation in reinforced concrete composite beam. The elements without stirrups in the connection surface between precast and complementary concrete failed in vivid manner while adhesion between concrete layers was lost. Beams without stirrups in the connection area concerned in current research failed in more discrete way, because of the fact that reinforcement took part in bearing loads causing separation of the layers. As the result there was not obtained failure of the connection surface. The article proved usefulness of presented methods to determine the moment of connection surface cracking and to observe other processes in the element.
\end{abstract}

Key words: digital image correlation (DIC), acoustic emission (EA), composite beam, crack propagation 